\title{
MOTIF PENGGUNAAN GADGET SEBAGAI SARANA PROMOSI BISNIS ONLINE DI KALANGAN MAHASISWA UIN SUNAN KALIJAGA
}

\author{
Nurul Izzati \\ Program Studi Kajian Komunikasi dan Masyarakat Islam (KKMI), Prodi Interdiciplynari \\ Islamic Studies, Universitas UIN Sunan Kalijaga, Jl. Marsda Adisucipto, Daerah Istimewa \\ Yogyakarta, No Telp. (0274) 589621 \\ Email: nuzzaizzati@gmail.com
}

\begin{abstract}
The presence of gadgets mainly in the form of smartphones has much to contribute in everyday life, as a media gadget information search, interacting, get entertained, even for the purpose of online business activities for today is widely used among students of UIN Sunan Kalijaga. This study aimed to describe the motives of use gadgets as online business promotion tool among students UIN Sunan Kalijaga. The research approach uses qualitative approach with descriptive qualitative method, focus of research is the use of gadgets motivation among students. Respondent with purposive sampling. The research found patterns of use gadgets as a means of business promotion online, such as, First, the use of gadgets are considered more convenient, easy and simple to do promotions, Second, Online Business is suitable for small businesses run by selling a variety of products. Third, Doing business online using a gadget or self-awareness initiative of informants in sufficient portion of the needs as well as training yourself to be an independent figure.
\end{abstract}

Keyword: Motive, Gadget, Online Bisnis.

\begin{abstract}
Abstrak
Kehadiran gadget terutama dalam bentuk smartphone telah banyak memberikan konstribusi dalam kehidupan sehari-hari, gadget sebagai media pencarian informasi, melakukan interaksi, mendapatkan hiburan, bahkan hingga untuk keperluan kegiatan berbisnis secara online untuk saat ini memang banyak digunakan di kalangan mahasiswa UIN Sunan Kalijaga. Penelitian ini bertujuan untuk mendeskripsikan motif penggunaan gadget sebagai sarana promosi bisnis online dikalangan mahasiswa UIN Sunan Kalijaga. Adapun pendekatan penelitian menggunakan pendekatan secara kualitatif dengan metode deskriptif kualitatif, fokus penelitian yaitu motivasi penggunaan gadget di kalangan mahasiswa. Penentuan responden dengan purposive sampling. Hasil penelitian ditemukan motif penggunaan gadget sebagai sarana promosi bisnis online yaitu : Pertama, penggunaan gadget dianggap lebih nyaman, mudah dan simple dalam melakukan promosi, Kedua, Bisnis Online cocok dijalankan untuk usaha kecil dengan menjual beragam produk. Ketiga, Berbisnis secara online menggunakan gadget merupakan inisiatif atau kesadaran diri dari informan dalam mencukupi sebagian kebutuhan serta melatih diri untuk menjadi sosok yang mandiri.
\end{abstract}

Kata Kunci: Motif, Gadget, Bisnis Online

\section{Pendahuluan}

Perkembangan zaman yang dinamis dan terus menunjukkan kemajuan yang begitu pesat dalam segala aspek bidang kehidupan, seperti pada era sekarang yang disebut sebagai era kekinian atau modern telah banyak menyebabkan perubahan-perubahan sosial yang terjadi di kalangan masyarakat. Pengaruh teknologi menjadikan orang-orang begitu bergantung akan kehadirannya, terlebih setelah kemunculan internet di mana orang-orang dengan mudah memperoleh beragam informasi.

Informasi-informasi dapat diakses dengan menggunakan fasilitas elektronik gadget seperti smartphone, komputer, laptop, tablet dan e-reader dengan fitur internet. Fenomena yang ada di tengah masyarakat, khususnya masyarakat perkotaan dan tak sedikit juga masyarakat pedesaan mulai mengubah cara pandang 
dalam mendapatkan informasi yang dibutuhkan dan beralih mengikuti perkembangan zaman, masyarakat lebih menyukai hal-hal praktis tanpa harus menghabiskan tenaga dan materi. Kemudahan yang ditawarkan oleh gadget dengan segala aplikasi unggulan misalnya media sosial yang mampu memangkas jarak dan menyebarkan informasi sehingga menjadikan gadget sebagai bagian yang tidak dapat dipisahkan dari aktifitas kehidupan sehari-hari.

Perkembangan teknologi begitu pesat, trend gadget terus merebak di Indonesia, semua kalangan baik anakanak, remaja dan dewasa berlombalomba untuk dapat memiliki produk gadget dengan tujuan sebagai pemenuhan kebutuhan dalam mendapatkan informasi secara cepat dan dengan waktu yang singkat, dari beragam produk yang beredar di masyarakat, namun yang umum digunakan yaitu bentuk smartphone. Adapun dari berbagai merk paling populer yang ditawarkan saat ini adalah android dan blackberry. Ketersediaan smartphone dengan fitur internet sebagai jaringan dengan tingkat akses yang mengglobal dan beberapa fasilitas dapat dimanfaatkan untuk berbagai keperluan baik dalam dunia bisnis maupun non bisnis. (Irena Anggita Nurul Adha \& Ratri Virianita, 2010: 380).

Berbicara mengenai trend pemakaian smartphone maka yang paling aktif dan mudah ditemui pemakaiannya terjadi dikalangan mahasiswa. Selain sebagai medium untuk mengakses informasi secara individual, juga digunakan sebagai media interaksi dengan membentuk grup-grup antara mahasiswa dengan mahasiswa maupun mahasiwa dengan dosen, yaitu melalui aplikasi media sosial yang terdapat di dalamnya seperti BBM, Facebook, Line, Whatsapp, dan Instagram. Beberapa mahasiswa UIN Sunan Kalijaga diantaranya juga menggunakan dan memanfaatkan media sosial untuk promosi bisnis online.

Adapun penggunaan media sosial untuk promosi bisnis online tidak terlepas dari adanya motif-motif tertentu yang diinginkan oleh setiap individu atau suatu tujuan yang dikehendaki, pengertian dari motif itu sendiri adalah yang mencakup penggerak, keinginan, rangsangan, hasrat dan dorongan dalam diri seseorang sehingga menyebabkan ia berbuat sesuatu secara singkat atau dengan kata lain yang mendasari perilaku individu tersebut. (Sunaryo, 2004: 135)

Berdasarkan hal tersebut maka timbul pertanyaan bagaimana motif penggunaan gadget sebagai sarana promosi bisnis online dikalangan mahasiswa UIN Sunan Kalijaga? Penelitian ini bertujuan untuk menemukan motif kalangan mahasiswa UIN Sunan Kalijaga dalam penggunaan gadget maupun motif melakukan bisnis online.

Motif adalah kebutuhan, keinginan dan dorongan. Motivasi seseorang juga tergantung kepada kekuatan motifnya. Motif dengan kekuatan yang cukup besarlah yang akan menentukan perilaku seseorang. Kekuatan motif juga dapat berubah jika terpuaskannya kebutuhan dan jikalau kebutuhan sudah terpenuhi maka akan terjadi penurunan terhadap motif dan beralih kepada kebutuhan lain dan seterusnya, sedangkan motivasi adalah kemauan untuk berbuat sesuatu serta sebagai salah satu faktor penentu dalam pencapaian tujuan. Motivasi berkaitan erat dengan dorongan atau kekuatan yang berada dalam diri manusia. (Tria Yulius Sapitri dan Jurry Hatammimi: 04).

Atribut yang menjadi motivasi wanita dalam berwirausaha yaitu (Endang, 2012: 63-69); 1) Mandiri secara ekonomi yaitu ketika seseorang mampu memenuhi keinginan dengan baik tanpa harus bergantung kepada 
orang lain dalam mengambil keputusan bertindak termasuk untuk mencukupi kebutuhannya. 2) Merasa kurang puas dengan pekerjaan yang ada yaitu ketika seseorang merasa kurang puas dengan pekerjaan yang sedang ditekuni saat sekarang, sehingga dapat memicu seseorang untuk merintis usaha sendiri. 3) Pengangguran yaitu ketika orang yang menganggur dan tidak menemukan lahan pekerjaan maka cenderung akan memulai bisnis. 4) Mencari tantangan yaitu wirausaha adalah orang-orang yang menaruh minat dan menyukai usahausaha yang menantang untuk mencapai kesuksesan. 5) Keinginan pribadi yaitu kemauan yang kuat serta rasa percaya diri yang tinggi dengan tekad yang akan mampu mengatasi semua permasalahan di lapangan. 6) Kebanggaan diri yaitu status sebagai pemilik perusahaan atau suatu usaha akan memberikan kebanggaan tersendiri dibandingkan status hanya sebagai seorang karyawan. 7) Tradisional atau turun-temurun yaitu sikap dan cara berpikir serta bertindak yang selalu berpegang teguh kepada norma, adat kebiaasaan menurut tradisi yang ada. 8) Kesempatan kerja yaitu ketika entrepreneur menciptakan lapangan pekerjaan dan bukan mencari pekerjaan. 9) Bantuan finansial yaitu dengan memasuki arena bisnis atau memulai usaha baru untuk mencari sumber dana dan fasilitas baik uang maupun pemodal. 10) Pengetahuan teknis yaitu memiliki kompetensi dalam bidang tertentu sesuai dengan bentuk usaha yang akan dipilih. 11) Dorongan keluarga yaitu keluarga mempunyai peran dalam menumbuhkan dan mempercepat seseorang untuk mengambil keputusan dikarenakan orang tua berfungsi sebagai konsultan pribadi. 12) Penggunaan dana tidak terpakai yaitu ketika faktor yang menjadi motivasi seseorang untuk berwirausaha karena adanya ketersediaan dana yang menganggur. 13) Fasilitas infrastruktur yaitu ketika tersedianya infrastruktur yang memadai mengacu adanya pasar yang harus tersedia dalam mengembangkan kewirausahaan. 14) Pengalaman kewirausahaan yaitu adanya pendidikan formal dan pengalaman bisnis kecil-kecilan dapat menjadi potensi utama untuk menjadi wirausaha yang berhasil. 15) Potensi pasar yaitu peluang pasar sekecil apapun harus diidentifikasi dengan baik. 16) Keinginan keluarga yaitu seseorang memulai usaha dikarenakan keluarga mereka sudah memiliki usaha sebelumnya, tinggal anggota keluarga untuk membuka usaha sendiri maupun meneruskannya. 17) Status sosial yaitu seseorang untuk memperoleh gengsi atau status dan dikenal orang banyak. 18) Latar belakang keluarga yaitu anggota keluarga cenderung meniru pola pikir, cara kerja dan sikap entrepeneur dari keluarganya.

Kemudahan yang ditawarkan oleh internet menyebabkan banyak bermunculan jenis usaha-usaha baru dalam kategori online yang menjual berbagai jenis produk. Bisnis online atau online shop adalah sebagai media promosi dan pemasaran bagi produk maupun jasa yang akan diperdagangkan, bisnis online hanya bisa diakses dengan menggunakan fitur internet untuk menampilkan katalog berupa tulisan maupun gambar kepada konsumen.

Bisnis online merupakan bisnis yang bersifat mobile di mana dalam melakukan kegiatan bisnis dapat diakses kapan dan darimana saja, pembeli dapat memesan produk atau barang online dengan menggunakan media seperti Smartphone, laptop, notebook, komputer dan lain sebagainya.

Penelitian ini dapat dianalisis melalui teori Ekologi Media. Ide utama dibalik teori ekologi media bahwa Mc Luhan melihat pengaruh dari teknologi media 
terhadap masyarakat. Pemikiran Mc Luhan memiliki tiga asumsi yaitu: (Adul Karim Batubara, 2014: 134) 1) Media melingkupi setiap tindakan di dalam masyarakat yaitu media tidak dilihat dalam artian yang sempit seperti surat kabar/ majalah, radio, televisi, film atau internet tetapi Mc Luhan melihat apapun itu yang bisa digunakan sebagai medium oleh manusia. 2) Media memperbaiki persepsi kita dan mengorganisasikan pengalaman kita yaitu dimana teori ekologi media melihat media sebagai sesuatu yang memberi pengaruh kepada manusia secara langsung. 3) Media menyatukan seluruh dunia yaitu di mana Mc Luhan berasumsi bahwa setiap kejadian atau peristiwa yang terjadi di belahan dunia lain dapat diketahui atau menjalar ke belahan dunia lain dengan sebutan desa global. Melalui media online mahasiswa termotivasi untuk berbisnis guna menambah pendapatan dan melatih kemandirian.

\section{Metode Penelitian}

Pendekatan penelitian ini yaitu secara kualitatif. Penelitian kualitatif adalah mencari pengertian yang mendalam tentang suatu gejala, fakta, dan realita, masalah serta peristiwa yang dapat dipahami apabila peneliti menelusurinya secara mendalam dan tidak hanya terbatas pada pandangan permukaan saja, demikian merupakan ciri khas penelitian kualitatif.

Penelitian ini menggunakan metode deskriptif dengan tujuan menggambarkan peristiwa yang sedang berlangsung saat ini, serta mencoba menganalisis bagaimana motif penggunaan gadget sebagai sarana promosi bisnis online di kalangan mahasiswa UIN Sunan Kalijaga baik dalam penggunaan gadget maupun motif melakukan bisnis online dengan menggambarkan informasi apa adanya.

Pelaksanaan penelitian kualitatif tidak menggunakan sampel sebagai bagian yang mewakili dari populasi, sehingga jumlah bnyaknya dari informan tidak menjadi patokan. Pemilihan informan dengan menggunakan purposive sampling di mana informan yang dipilih dapat mewakili informasi dengan kedalaman dan kemampuan dalam memberikan kelengkapan data.

Langkah-langkah memperoleh data di lapangan dilakukan dengan: 1) wawancara mendalam kepada beberapa informan yang diambil secara acak dari mahasiswa UIN Sunan Kalijaga yang aktif dalam melakukan promosi bisnis online di media sosial seperti BBM dan Whatsapp melalui smartphone; 2) Observasi atau pengamatan langsung terhadap motif penggunaan gadget sebagai sarana promosi bisnis online di kalangan mahasiswa UIN Sunan Kalijaga di mana peneliti mengamati langsung proses promosi bisnis online di media sosial. Data dianalisis secara kualitatif.

\section{Hasil Penelitian dan Pembahasan}

Penelitian ini melibatkan beberapa pengguna gadget yaitu informan mahasiswa UIN Sunan Kalijaga di mana gadget digunakan sebagai sarana promosi bisnis online dengan memanfaatkan smartphone untuk melakukan bisnis, menjual berbagai macam bentuk produk seperti pakaian, produk kecantikan dan produk kesehatan.

Salah satu informan adalah Sa'adah Ritonga dari Fakultas Ushuluddin dan Pemikiran Islam menggunakan gadget sebagai media untuk berbisnis online karena dianggap selain lebih simple juga mudah dalam proses penjualan barang berupa produk kecantikan dan kesehatan. Penggunaan aplikasi bisnis online yaitu melalui BBM, Whatsapp dan Facebook, ketiga aplikasi tersebut sangat efesien dalam melakukan promosi maupun penjualan produk ataupun barang secara online.

Desi Kumalasari dari fakultas Tarbiyah sebagai informan lainnya 
mengatakan bahwa menggunakan gadget karena dianggap lebih nyaman dalam melakukan promosi tanpa harus menetap di satu tempat atau datang dari rumah ke rumah, kemudian dapat juga mempromosikan berbagai macam produk untuk dijual sehingga sangat memudahkan dalam proses penjualan seperti jilbab, produk kesehatan dan kecantikan.

Bisnis Online memiliki keuntungan sendiri bagi mahasiswa UIN Sunan Kalijaga disebabkan penjualan yang praktis dan mudah. Proses penjualan bisa dilakukan kapan saja, tidak memerlukan tempat usaha sehingga memberi kenyamanan dan sangat efesien dibandingkan dengan bisnis offline, karena mengingat status sebagai mahasiswa yang dituntut kehadiran dan fokus dalam proses belajar lebih sulit membagi waktu jika harus berbisnis secara offline. Bisnis secara offline akan menyita banyak waktu, serta sulit untuk menjangkau banyak orang sehingga bisnis secara online menjadi pilihan bagi beberapa kalangan mahasiswa UIN Sunan Kalijaga.

\section{Motif Penggunaan Gadget Sebagai Sarana Promosi Bisnis Online}

Semenjak kemunculan internet ditambah dengan zaman yang semakin maju, kini masyarakat mulai meninggalkan metode lama di mana dulu interaksi yang dijalin lebih sering dengan cara tatap muka. Era modern telah merubah pola interaksi antara individu dengan individu, individu dengan kelompok bahkan antar kelompok dalam proses komunikasi.

Kehadiran Gadget terutama dalam bentuk smartphone telah banyak memberikan konstribusi dalam kehidupan sehari-hari, gadget sebagai media pencarian informasi, melakukan interaksi, mendapatkan hiburan, bahkan hingga untuk keperluan kegiatan berbisnis secara online untuk saat ini memang banyak digunakan di kalangan mahasiswa UIN Sunan Kalijaga. Interaksi menjadi lebih mudah, cepat dan praktis dengan penggunaan gadget, bahkan gadget telah menjadi gaya hidup dari seseorang, hampir semua kalangan menggunakan gadget dan telah menjadi bagian hidup yang sulit untuk dipisahkan.

Penggunaan gedget sebagai media untuk berbisnis maka tidak lepas dari keunggulan serta kemudahan yang ditawarkan oleh produk-produk gadget tersebut. Layaknya di Indonesia gadget atau yang lebih sering dipakai dalam bentuk smartphone dimiliki hampir oleh tiap orang. Smartphone lengkap dengan fitur internet memudahkan dalam melakukan proses komunikasi bisnis online di jejaring sosial. Bentuk jejaring sosial seperti BBM, Whatsapp, Line, Kakao Talk dan facebook selalu diakses oleh banyak orang.

Hal ini sesuai dengan asumsi teori ekologi media di mana Sa'adah Ritonga dan Desi Kumalasari serta pengguna smartphone lainnya yaitu setiap orang memiliki kebutuhan dan ketergantungan terhadap media dalam menjalankan fungsi komunikasi untuk berbagai alasan tentunya. Kehadiran teknologi khususnya teknologi komunikasi tidak dapat dipisahkan dari kehidupan di era modern.

Level dan konteks komunikasi bermedia internet selain aktivitas dan proses komunikasi sebagai pertukaran data namun tetap melibatkan manusia sebagai pemberi konteks atau situasi pada aktifitas dan proses komunikasi baik secara individual, group maupun organisasi dan lain sebagainya. (Edwi Arief Sosiawan, 60-75)

Tingkat penggunaan media sosial yang tinggi dapat dimanfaatkan untuk beragam keperluan proses komunikasi di dalamnya, salah satunya yaitu sebagai ajang untuk berbisnis. Tampilan media sosial di mana penggunanya dapat mengatur foto profile, melihat 
isi pengguna yang tersedia hingga mengundang atau menerima, mengirim foto, pesan suara, video, bergabung di grup dan lainnya sangat memungkinkan untuk dijadikan lahan berbisnis dan biasa disebut dengan bisnis online. Hal ini menjadi penggerak dan melahirkan motif untuk berbisnis di media sosial.

Tingkah laku manusia pada hakikatnya selalu berkaitan erat dengan motif tertentu. Motif adalah hal abstrak yang selalu dikaitkan dengan perilaku, defenisi motif yaitu menyangkut penggerak, keinginan, rangsangan, hasrat, pembangkit tenaga dan alasan serta dorongan dalam diri manusia sehingga mendorong suatu perbuatan. (Sunaryo, 2004: 135).

Gadget oleh beberapa kalangan mahasiswa UIN Sunan Kalijaga juga dipakai untuk terjun dalam bisnis online dengan melakukan usaha kecil atau menengah dengan menjual berbagai produk seperti baju, sepatu, jilbab, aksesoris hingga produk-produk kesehatan dan kecantikan (kosmetik). Produk-produk dipromosikan dengan meng-upload foto dan keterangan produk di media sosial.

Sa'adah Ritonga dan Desi Kumalasari mengatakan bahwa usaha kecil sangat efektif dilakukan secara online terutama bagi mahasiswa dikarenakan hanya dengan modal yang kecil dan dapat dijalankan hanya dengan penggunaan gadget sebagai sarana promosi. Berbisnis secara online merupakan inisiatif atau kesadaran diri sendiri yang dialami oleh kedua informan untuk dapat hidup mandiri dan mencukupi sebagian kebutuhan serta melatih diri untuk menjadi sosok yang mandiri.

Irena Anggita Dan Ratri Virianita menjelaskan bahwa usaha kecil atau menengah (UKM) dapat dijalankan dengan memanfaatkan internet dalam kegiatan berbisnis, memasuki Era global seperti saat ini dengan penggunaan teknologi informasi sehingga dapat meningkatkan transformasi bisnis melalui kecepatan, ketepatan dan lebih efesien. Keberhasilan suatu usaha kecil sangat bergantung kepada pemilik bisnis, kemajuan teknologi informasi telah menjadi pilihan dalam pemanfaatan internet untuk kegiatan bisnis. (Irena Anggita \& Ratri Virianita, 2010: 380).

\section{Simpulan}

Perkembangan teknologi komunikasi telah mempermudah setiap orang dalam melakukan berbagai hal. Teknologi komunikasi dalam bentuk gadget telah memberikan manfaat yang berarti bagi kalangan mahasiswa UIN Sunan Kalijaga di mana gadget atau smartphone digunakan oleh Sa'adah Ritonga dan Desi Kumalasari sebagai mahasiswa UIN Sunan Kalijaga untuk melakukan usaha kecil dengan berbisnis secara online.

Smartphone dengan fitur internet serta aplikasi media sosial seperti BBM, Whatsap dan Facebook dapat menjadi wadah dalam melakukan promosi suatu produk atau barang baik berupa pakaian, produk kecantikan maupun produk kesehatan. Ditinjau dari teori ekologi media di mana orang-orang selalu memiliki kebutuhan terhadap media, yang dimaksud disini bukan hanya media dalam artian sempit seperti koran, majalah, televisi, laptop dan sebagainya, namun yaitu apapun medium yang digunakan terutama yang berkaitan dengan teknologi komunikasi dan mempunyai dampak dalam perubahan sosial.

Sa'adah Ritonga dan Desi Kumala Sari menggunakan gadget dalam bentuk smartphone untuk melakukan bisnis online disebabkan kemudahan, kenyamanan dan lebih simple dalam melakukan promosi maupun transaksi penjualan suatu produk atau barang. Berbisnis secara online dapat melatih diri menjadi sosok yang mandiri dan dapat mencukupi sebagian kebutuhan. 
Implikasi penelitian ini adalah berbisnis secara online memberikan kemudahan dan kecepatan baik dalam ajang promosi maupun transaksi penjualan, konsumen dapat dengan mudah memesan produk ataupun barang di media online dengan beragam variasi produk yang ditawarkan, selain kemudahan dalam pemesanan namun pelanggan tidak dapat mengetahui atau melihat langsung suatu produk yang telah dipesan oleh karena itu bagaimana penjual untuk benar-benar memperhatikan kualitas suatu produk dan sesuai dengan tampilan foto serta keterangan produk yang di publikasikan baik itu di BBM, whatsap maupun Facebook.

\section{Daftar Pustaka}

Abdul Karim Batubara, (2014), Media Ecology Theory, Jurnal Iqra' Vol 08. No.02, Hal. 134-135.

Anton Ramdan, Sukses Bisnis Online (Panduan Membangun Toko Online Profesional) [Online] https:// books.google.co.id/books? id = FFNFCQAAQBAJ \& pg $=$ PA9 \& dq $=$ bisnis + online $\& \mathrm{hl}=$ en \& sa $=X$ \& ved $=$ 0ahUKEwj Ep7bO9Lz KAhWOw I4KHcqKDaEQ 6AEIUDAH \# $\mathrm{v}=$ onepage $\& \mathrm{q}=$ bisnis $\% 20$ online $\& \mathrm{f}=$ false, [accessed 20 Januari 2016]
Edwi Arief Sosiawan. (2011). Penggunaan Situs Jejaring Sosial sebagai Media Interaksi dan Komunikasi di Kalangan Mahasiswa. Jurnal Ilmu Komunikasi Vol. 09 No. 01, Hal. 60-75.

Endang. (2012). Faktor-Faktor Motivasi Berwirausaha Terhadap Keberhasilan Pengusaha UKM. Jurnal Profit. Vol. 6 No. 1 Hal 63-69.

Irena Anggita Nurul Adha, Ratri Virianita (2010). Sikap dan Intensi Pemanfaatan Internet dalam Kegiatan Bisnis. Jurnal Departemen Sains Komunikasi dan Pengembangan Masyarakat. Hal 380389.

Sunaryo. 2004. Psikologi Untuk Keperawatan, Jakarta: Penerbit Buku Kedokteran EGC.

Tria Yulius Safitri, Jurry Hatammimi, Analisis Faktor-Faktor yang Memotivasi Wanita Berwirausaha Melalui Bisnis Online (Studi pada Mahasiswi Sekolah Bisnis di Bandung). Jurnal Manajemen Bisnis dan Informatika. Hal .04. 